\title{
Children on the Street: Reasons of Their Existence and Their Commonly Observed Effects
}

\author{
Anna C. Bocar
}

\begin{abstract}
This study desired to determine the underlying reasons contributory to the existence of the children on the street of the city of Ozamiz and the common effects that they have observed. The descriptive survey method was used in the study and it utilized the statements from online articles to generate the survey questionnaire that suits to the chosen environment. This study found that there are more girls than boys on the street of the subject city. There were three factors that pushed the respondents and strongly contributed to their existence on the street of the city. These are being an orphan, the war and the natural disasters. The results did not exclude poverty. The study also showed that verbal abuse from the public and child born on the street are sometimes the most common effects observed by the respondents. Furthermore, the study showed that majority of the effects (as utilized in this study) happened in few times. This signifies that the reasons which are classified into two groups namely: the push and pull factors, and the effects commonly observed by the children on the street in the city are lesser in degree.
\end{abstract}

Index Terms-Effects, reasons, street children.

\section{INTRODUCTION}

The children for many families are on top of parents' priorities. They are sent to school in order to have their formal studies and be nurtured on the many aspects in life other than those which the parents could extend to them. But sometimes there are families who forgot that sending to school is just one of the numerous obligations of parents. Under Philippine laws, it is the right of the children to have a decent life and be sent to school.

There are children, who spend and sleep in a house with ill-prepared adults, and some live entirely in the streets and have no adult supervision or care, the latter are considered street children. They are most often deprived of family care and protection. Most children on the streets are between 10 to 14 years old, and their population between different cities varied. Particularly street children are those not taken care of by their parents or other guardians for protection. In developing countries street children exist in many major cities and these street children may be the subject of abuse, neglect, and exploitation by local residents and transients in the said place.

Sometime in 1997, there was a campaign called Zero Street Children for Philippines 2000 which targets 5,131 street kids and their families. This program aim involved not only government agencies but non-government organizations as well [1]. I observed in some streets in Manila that there are

Manuscript is received March 20, 2014; revised May 22, 2014.

Anna C. Bocar is with the La Salle University, Ozamiz (e-mail: acb502011@yahoo.com). a number of street children that slept on the side of closed establishments at night time and some are found in Luneta Park lying on the benches or on the street itself even at late hours in the evening. I ponder that there are still wide range in this program that needs to be realized because until at present children are still evident on the street. This situation in this big city is not remote in Ozamiz. Hence, in this study I desire to determine the underlying reasons contributory to the existence of the children specifically on the street of Ozamiz and the common effects that they have observed or experienced.

\section{A. Review of Related Literature}

This study was inspired by the online articles that speak about street children. I have learned that they made up a portion of the children who are committed to correctional institutions (prisons). The term street children refer to children for whom the streets have become their real home more than their family. This includes children who might not necessarily be homeless or without families, but who live in situations where there is no protection, supervision, or direction from responsible adults. The negative impressions from the society or public arise not only against the children themselves but also to their parents. This situation is deemed to be real in some places [2].

Another article defined street children as: "The young people who spend a considerable time living and/or working on the streets of the world's cities." Different studies describe street children in different ways; however, two general categories have been frequently used to describe them namely: (1) children living and working in the street and (2) children working on the streets who maintain regular contact with their families. Furthermore, the study mentioned above enumerates the real situation of street children in Asia as follows: "working street child works from 6 to 16 hours, often in a combination of occupations; they usually come from broken or large families with six to ten children per family; generally they are malnourished and anemic, many of them are physically stunted (undersized); they suffer psychologically from undue family pressures, abuses and neglect at home. The study declared that very often street children develop low self-esteem; they are prone to street fights and bullying from bigger youth, harassment from policemen, suspicion and arrest for petty crimes, abuse and torture from misguided authorities. This study also found that there are more boys than girls on the street [3].

A study explains street children into two main categories: (1) children on the street are those engaged in some kind of economic activity ranging from begging to vend. Most of them go home at the end of the day and contribute their earnings to their family. They may be attending school and 
retain a sense of belonging to a family. Because of the economic fragility of the family, these children may eventually opt for a permanent life on the streets and (2) children of the street actually live on the street (or outside of a normal family environment). Family ties may exist but are tenuous and are maintained only casually or occasionally [4]. Jobless parents and poverty were the reasons pointed out by a 12 - year old child who turns to be a beggar [5]. Poverty and the failure of the government to protect and extend help to the street children are also considered to be the reasons why they are imprisoned [6]. An eight year old boy stops his studies and sells cigarettes and candies on dangerous streets and sidewalks in Zamboanga City to help his poor family [7]. "Statistically an estimate of 20,000 children is in prison in the Philippines throughout a single year. They are usually falsely accused because they are homeless, vulnerable and cannot defend themselves". They are the victims of unjust and cruel system of imprisonment [6].

Some people, rich and poor experience many uncomfortable encounters since some of the street children approached people with snotty-nosed, barefooted, half-naked asking for food. Others tapped on tinted car windows, and asked for money. The major highways, outside shopping centres, markets are the areas that there are many people to beg from, tourist attractions to sell small items to and there are also plenty of areas to play, restaurants that hand out free food, fountains to wash in, are the places where the street children like to stay[8]. Boys age between 13 and 18 years old are seen staying at stairway in Manila. A certain Lar explains that "most of the children are victims of poverty, and the consequences of poverty are broken families, violence, drugs, alcoholism, and in many cases sexual abuse". He explains further that, deciding to run away from home because of lots of beating was considered a great decision made by a child at the age of 10 [9]. Environmental inequalities are experienced by children of poor families. These children are unprotected from unstable and chaotic households, family turmoil, violence and separation from their families. At home, they lack books to read and no computers to use to supplement their knowledge. Usually they watch more television shows and their parents have less participation in their school activities. Another contributory factor of children in poverty is the environmental risks such as homes of lower quality, crowded and noisy. Dangerous neighborhoods, poor municipal services are also considered in a certain study [10].

Moreover, armed conflict damaged infrastructure. The health care services for children and education are at risks. The personal insecurities of the people increase [11]. The feeling of the family that they cannot extend enough support for their children due to poverty is the core reason that a family member left his child at the orphanage. Many of the Afghan parents temporarily leave their children to orphanages having known that children will receive food, clothes, and be sent to school [12].

Furthermore, the earthquake that struck Japan is an example of a natural disaster which took the life of children's parents and as such causes them to become orphans. The children were displaced and given no decent learning environment due to the said natural disaster [13]. Natural disaster does not only happen in Japan but also in the Philippines. Yolanda, one of the world's strongest typhoons struck the Philippines and number of people was dead or missing. UN humanitarian chief Valerie Amos said that huge numbers of people were exposed to bad weather which babies, children, and mothers are in danger [14].

In a certain study, orphans were classified into three. These are the near orphan, one-half orphan and double orphans. The near orphan refers to the children with chronically ill parent who will become orphans in the next year. The one-half orphans are those who have lost only one of their parents (either no mother or no father). Meanwhile, the double orphans are children under 18 years of age who have lost both parents [15]. A study pointed out that there are two types of factors which describe the attitudes of the orphans. These two factors are internal and external factors. Internal factor signifies the terrible self-consciousness above controlled behavior. It is also called as depressed factor in which children are deprived by parents and lack essential psychological support at early stage of age. On the other hand, external factor refers to aggressive antisocial uncontrolled behavior. The children are separated from their parents and as such they lack parental attachment. The children's aggressive and rebellious attitudes are evident. Violence was thought by them as the resolution of conflict [16].

Saenger expressed that the belief of the father that he is absolutely powerful in the family may mean as a dysfunctional behavior pattern which could be transported on by the children in their adulthood. Children's observation on the inappropriate conduct of parents could give them negative impressions and consequently would result to violence [17]. Another study stressed that the painful and traumatic experience of the children with their family contributed to the subsequent addictive behavior which in return affected the familial relationships. Drug addiction is a societal problem. Families and communities are destructed due to drug addiction [18]. Some street children use forbidden solvents to ease the pains and loneliness [6]. Street children who are found sniffing rugby (a brand of glue) could develop general publics' distrust, frustration, and hostility towards street children [8]. Dizon held that one study showed that almost all the minors killed since 1998 were "street children or urban living and working children" [19]. Talusan added that some street children wipe the shoes of the Jeepney passengers, found at the train station begging for money and food [20]. The Department of Labor in the Philippines revealed that there are "children living on the streets engage in informal labor activities like begging. Domestic service and commercial sex industry production of pornography are also other ways which involve street children" [21].

\section{B. The Problem}

The intention of this study was to gaze into the reasons contributory to the existence of street children as ascertained by the respondents. Purposely, the study was undertaken to answer the following: (1) what is the reason that strongly contributes to the existence of the children on the street of Ozamiz? (2) Among the effects that the respondents observed in their street existence what is the most common to them? 


\section{Significance of the Study}

This study is important to the: Children on the Streets. Through this study the situation of the children on the street could be improved. Government Officials: The results of this research will serve as a guiding principle for them to curtail the existence of street children in the city if it cannot be avoided through the enactment of considerable measures and extension of substantial help through different programs. Community Officials: They will find this study a valuable device in their planning concerning the development of some programs that will promote the welfare of the street children in their area of responsibility. La Salle University: The university will become more responsive and able institution to produce further creative strategies of community extensions to help street children. Administrators of La Salle University: They can assemble from the results of this research some programs that will support the city government's plans. Parents: They will become conscious on what are the conditions that they need to improve in the rearing of their children. The result of this investigation can widen their awareness on what are the situations that they should act upon so that children will stay in their own home and not to go astray. Local Residents: They will be able to widen their minds and understand why these children are found on the streets. Understanding on the situations that are contributory to the existence of street children would help to awaken their civic consciousness and social responsibility.

\section{METHOD}

The descriptive survey method was utilized in this study. The study was conducted in the city of Ozamiz with the assistance of Ms. Isidora Cejudo, the support staff of the Department of Social Welfare of the city.

\section{A. Research Respondents}

Most children on the streets are between the ages of 10 and 14 years old; however, in this study the researcher focused on the street children having the ages above 8 to below 16 , male and female. Ms. Isidora Cejudo, support staff of the Department of Social Welfare in Ozamiz City identified the respondents and their ages (personal communication, December 27, 2010). There were twenty eight who were chosen respondents in this study.

\section{B. Research Instruments}

The instrument utilized in this study was sourced from an online article entitled "Why are there street children?" (n.d.). The researcher considered the items in this article and made slight modifications to fit with the respondents and environment of the study. Based on this article the reasons of children's existence on the street are broken down into two groups. The 1st group is called as the push factors and the 2nd group is called as the pull factors. Poverty is another reason outside the two groups.

The article presented the following reasons: Poverty. This means that the respondents come from areas of poor housing with little access to running water or adequate sanitation. The push factors are: 1) war (this refers to political/social unrest; fights between military and local rebels); 2) natural disasters which cause homelessness and displacement of people (such as typhoon, flood, drought, famine and other natural calamities); 3) Urbanization. The families move from rural to urban areas; 4) Orphans. No mother and father; 5) Dysfunctional family environment. Escape from the abuse of family members, or abandoned by parents. On the other hand, the pull factors are: 1) Gangs. This means that they have made friends on the streets and left home to become an official member of a gang. 2) Freedom. They are attracted by the temptation of freedom and entertainment in the city; no longer want to work for their parents and live with their brothers and sisters in a small shanty; 3)Drugs. They try glue sniffing or other drugs; 4) Prospect of a better life. They escape hardship and leave homes with the hope of making better life in the city. The instrument also presented the effects as follows: 1) violence from police/security firms; 2) verbal abuse from the public; 3) trafficking; 4 ) prostitution rings; 5) early death; 6) lack of access to education; 7) stealing; 8) children born on the streets; 9) begging; 10) drugs; 11) sickness/injuries. They are the bases of the present study.

\section{Statistical Treatment of Data}

For the purpose of determining the reasons contributory to the existence of street children each item or reason in the first set was followed by a numeric value $(1,2,3,4)$ for the respondents to choose. They are instructed to check the box that represents their possible response during the scheduled interview. The verbal scale and the qualitative description for respondents' answers are set as follows respectively: Never $(\mathrm{N})$ - this means that the reason has no contribution at all; Lightly contribute (LC) - this means that the reason contributed few times to the existence of children on the street in the city; Frequently Contribute (FC)- this means that the reason contributed majority of times to the existence of children on the street in the city; Strongly contribute (SC) this means that the reason contributed at all times to the existence of children on the street in the city.

Each item in the 2nd set which measures the effects that the respondents commonly observed by the children on the street in the city has also its numeric value (1, 2, 3, 4). The verbal scale and qualitative description are set as follows respectively: never - not at all; sometimes - this means that this effect happens in few times; often - this means that this effect happens frequently; always - this means that this effect happens all the time.

\section{Data Gathering Procedure}

The primary data were collected by using the interview schedule questionnaire and field observations as a supplementary method. For purposes of this study, before the administration of the survey questionnaire slight modification was made from the online source titled "Why are there street children?" [2]. The items were translated in the regional language which is Cebuano. Each item was read and carefully explained by the researcher to the respondents. It was purposely done for their better understanding since they are at their tender age. Survey questionnaires were collected then given answers was tallied, analyzed and interpreted using the frequency distribution table. 


\section{PResentation, ANALysis AND Interpretation of DATA}

This section presents, analyzes and interprets the data collected in this study. The data pertained to the reasons of the children's existence on the street and the effects that are commonly observed by them.

\section{A. Profile of the Respondents}

The respondents of this study consisted of thirteen males and fifteen females, ages above eight to below sixteen. This situation is similar to a certain study [3] which suggests that there are more boys than girls on the street.

\section{B. Poverty}

Poverty may also mean that a person is missing much in life. This suggests that the respondents not only lack financial and material things but also the attainment of good education. And because he/she wanted to have some of the material things to survive and intent to change in his/her life style he/she might look for ways to attain his/her objectives.

The first part of this study is to determine what reason that strongly contributes to the existence of children on the street of the Ozamiz city. This is measured through frequency distribution of every item or reason.

Table I below shows the result of the study with respect to poverty, one of the reasons of the existence of the street children.

TABLE I: POVERTY AS THE REASON FOR CHILDREN's EXISTENCE ON THE

\begin{tabular}{c|c|c|c|c|c|c|c|c}
\multicolumn{10}{c|}{ STREET } \\
\hline Reason & \multicolumn{2}{|c|}{ N } & \multicolumn{2}{|c|}{ LC } & \multicolumn{2}{|c}{ FC } & \multicolumn{2}{c}{ SC } \\
\hline & $F$ & $\%$ & $F$ & $\%$ & $F$ & $\%$ & $F$ & $\%$ \\
\hline Poverty & & & 12 & 0.43 & 6 & 0.21 & 10 & 0.36 \\
\hline
\end{tabular}

Based on the gathered data the 43 percent (which is the greater one of all the rates) of the respondents said that poverty lightly contributed to their existence on the street. This means that in few times poverty directs them to the street. This result is relative to what is visible in Manila, where boys whose age is between 13 and 18 years old are seen staying at stairway of the said place and it was described that most of the children are victims of poverty [9]. Evidently, this is the reason why children have to go away from their poor home conditions.

\section{Push Factors}

The Table II highlights the result of the study with regard to the different factors that push the respondents to be on the street.

Among the five items which were deemed as push factors to the existence of the street children in this study it is evident in the result that dysfunctional family environment is never a reason to be on the street for the 50 percent of respondents. This means that to escape the abuse from family members or being abandoned by parents is not a reason for them to exist in the street. The 39 percent of the respondents acknowledged that urbanization lightly contributed to the existence of children on the street. This can be seen not only in the city of Ozamiz but also in some big cities in the region that there were people who are moving their residence from one community to another community or city. This could be powered also by their hopes for a better life. On the other hand, the perception of the respondents splits up as regards to natural disaster item. The 32 percent believed that natural disasters which cause homelessness and displacement strongly contributed to their street existence; however, the other 32 percent said that natural disasters contributed lightly only to their existence on the street. The natural disasters that struck Japan and the Philippines displaced the children of very young ages and their exposure to bad weather placed them in danger [10]. Though only some of the respondents signify that natural disasters moved them to be on the street; however, this is worthy to think about since this children need attention for their well-being.

TABLE II: PUSH FACTORS AS THE REASONS FOR CHILDREN'S EXISTENCE

\begin{tabular}{l|c|c|c|c|c|c|c|c}
\multicolumn{1}{c|}{ Reasons } & \multicolumn{2}{c|}{ N } & \multicolumn{2}{c|}{ LC } & \multicolumn{2}{c|}{ FC } & \multicolumn{2}{c}{ SC } \\
\hline Push Factors & $F$ & $\%$ & $F$ & $\%$ & $F$ & $\%$ & $F$ & $\%$ \\
\hline $\begin{array}{l}\text { 1. War } \\
\text { (political/ } \\
\text { social unrest) }\end{array}$ & 7 & 0.25 & 7 & 0.25 & 3 & 0.11 & 11 & 0.39 \\
\hline $\begin{array}{l}\text { 2. Natural } \\
\text { disasters cause } \\
\text { homelessness } \\
\text { and displace } \\
\text { ment }\end{array}$ & 3 & 0.11 & 9 & 0.32 & 7 & 0.25 & 9 & 0.32 \\
\hline $\begin{array}{l}\text { 3.Urbani } \\
\text { zation }\end{array}$ & 9 & 0.32 & 11 & 0.39 & 3 & 0.11 & 5 & 0.18 \\
\hline $\begin{array}{l}\text { 4.Orphans } \\
\text { P.Dysfunc } \\
\text { tional family } \\
\text { environment }\end{array}$ & 8 & 0.29 & 6 & 0.21 & 2 & 0.07 & 12 & 0.43 \\
\hline
\end{tabular}

The 39 percent of the respondents affirmed that war and political/social unrest is also another factor that would strongly contribute to the push on the children to be in the street. The claim of these respondents is acceptable since the presence of armed conflict damaged infrastructure, and the health care services for children and education are at risks and certainly the personal insecurities of the people increase [11].

The 43 percent of the respondents declared that being an orphan would strongly contribute and move them forward to the streets. This means that this reason contributed at all times to the existence of street children. In this study, the general meaning of orphan is being employed and no classification was made whether near orphan, one half or double orphan [15]. The respondents are made to understand that orphan refers to one whose both parents are already dead. The result did not indicate that children are orphan for the reason that a family member left his child at the orphanage [12].

The four items under factors that pull the children to be in the street in Table III displays a high percentage of never. This means that for the majority of the respondents to be a member of gangs, aspiration for freedom, use of prohibited drugs have no contribution to their existence on the street. The public knew that drug addiction is a societal problem. Families and communities are destructed due to drug addiction [18]. In this study some of the respondents negate the use of prohibited drugs, membership of the gangs and aspiration for freedom. Although the percentage in each of the factors does not deny the fact that poverty could still lightly contribute to the reason of being on the streets. 


\section{Pull Factors}

The researcher noticed that in Table I, 43 percent believed that poverty lightly contributed to their existence on the street. The said result is relevant in relation to number 4 of the table below which shows that only 64 percent of the respondents show that these pull factors never affect them. This means that to some extent there is still percentage that prospect of a better life contributed their existence on the street.

TABLE III: PULl FACTORS AS THE REASONS FOR CHILDREN'S EXISTENCE ON THE STREET

\begin{tabular}{l|c|c|c|c|c|c|c|c}
\hline Reasons & \multicolumn{2}{|c|}{$\mathbf{N}$} & \multicolumn{2}{|c|}{ LC } & \multicolumn{2}{|c}{ FC } & \multicolumn{2}{c}{ SC } \\
\hline Pull Factors & $F$ & $\%$ & $F$ & $\%$ & $F$ & $\%$ & $F$ & $\%$ \\
\hline 1. Gangs & 17 & 0.61 & 7 & 0.25 & 3 & 0.11 & 1 & 0.03 \\
\hline 2. Freedom & 17 & 0.61 & 9 & 0.32 & - & - & 2 & 0.07 \\
\hline 3.Drugs & 20 & 0.72 & 1 & 0.03 & 2 & 0.07 & 5 & 0.18 \\
\hline $\begin{array}{l}\text { 4. Prospect of } \\
\text { a better life }\end{array}$ & 18 & 0.64 & 7 & 0.25 & - & - & 3 & 0.11 \\
\hline
\end{tabular}

\section{E. Effects Commonly Observed}

The Table IV below displayed the eleven items specified in this study which are considered as effects that can happen commonly to the children on the street. The results of the study clearly showed that violence from police/security firms never happen to be the common effects to the respondents.

The result in Table IV revealed that 100 percent of the respondents declared that violence from police/security firms is not at all an effect common to the respondents based on their observation. This result is different from the report of Human Rights Watch for Street Children since it stated that street children throughout the world are subjected to physical abuse by police [22]; however, the researcher considered such position in the general sense. The 97 percent of the respondents expressed that taking drugs is never a common effect to them. The possibility of this is positive in their case due to respondents' tender age and the influence of these prohibited drugs might not yet in their minds. There were only 93 percent of the respondents expressed that the other items in Table IV specifically trafficking and prostitution rings never happened at all. The result reflects also that only 3 percent thought that it happened all the time.

The 57 percent of the respondents marked that lack of access to education and stealing are never the effects common to them. This is not remote from the words given by Cejudo, as she said that "though these children are on the street some of them are enrolled in their formal education" (personal communication, December 27, 2010).

Only three items of the eleven obtained high percentage rate of respondents' answers which demonstrated that this effect happened sometimes. These are: verbal abuse from the public $(83 \%)$, and children born on the street $(83 \%)$ and sickness / injuries (79\%). This means that these three items are effects that are commonly experienced by the children on the street in few times. Furthermore, there are 3 percent who had observed that verbal abuse from the public, begging and early death happen frequently on the street. People in the $s$ public place most often are busy. Possibly their minds are preoccupied with itinerary and various schedules to cope up. They do not have so much time to think of the welfare of the least members of the society and their patience is very limited when disturbed. There are many uncomfortable encounters since some of the street children approached people with snotty-nosed, barefooted, half-naked asking for food. The tapping of car windows and asking for money [8] could also be reasons why others do not bother street children. These could also be the reasons why the public would utter unsavory words to the children on the street. Even though the results showed that there are only very few of the respondents who stated that asking money or begging from the people on the streets are resorted to by them, this can be considered as reliable in view of the fact that these children on the streets might not have something in their stomach to survive. Eventually this will result to early death.

\section{TABLE IV: EFFECTS COMMONLY OBSERVED BY THE CHILDREN ON THE} STREET IN THE CITY

\begin{tabular}{|c|c|c|c|c|c|c|c|c|}
\hline \multirow[t]{2}{*}{ Effects } & \multicolumn{2}{|c|}{ Never } & \multicolumn{2}{|c|}{ Sometimes } & \multicolumn{2}{|c|}{ Often } & \multicolumn{2}{|c|}{ Always } \\
\hline & $F$ & $\%$ & $F$ & $\%$ & $F$ & $\%$ & $F$ & $\%$ \\
\hline $\begin{array}{l}\text { 1. Violence } \\
\text { from police/ } \\
\text { security firms }\end{array}$ & 28 & 100 & - & - & - & - & - & - \\
\hline $\begin{array}{l}2 . \text { Verbal } \\
\text { abuse from the } \\
\text { public }\end{array}$ & 4 & 0.14 & 23 & 0.83 & 1 & 0.03 & - & - \\
\hline 3. Trafficking & 26 & 0.93 & 1 & 0.03 & - & - & 1 & 0.03 \\
\hline $\begin{array}{l}\text { 4. Prostitution } \\
\text { rings }\end{array}$ & 26 & 0.93 & 1 & 0.03 & - & - & 1 & 0.03 \\
\hline 5. Early death & 23 & 0.83 & 4 & 0.04 & 1 & 0.03 & - & - \\
\hline $\begin{array}{l}\text { 6. Lack of } \\
\text { access to } \\
\text { education }\end{array}$ & 16 & 0.57 & 10 & 0.36 & 2 & 0.07 & - & - \\
\hline 7. Stealing & 16 & 0.57 & 12 & 0.43 & - & - & - & - \\
\hline $\begin{array}{l}8 . \text { Children } \\
\text { born on the } \\
\text { streets }\end{array}$ & 5 & 0.17 & 23 & 0.83 & - & - & - & - \\
\hline 9. Begging & 16 & 0.57 & 11 & 0.39 & 1 & 0.03 & - & - \\
\hline 10 Drugs & 27 & 0.97 & 1 & 0.03 & - & - & - & - \\
\hline $\begin{array}{l}\text { 11. Sickness/ } \\
\text { injuries }\end{array}$ & 4 & 0.14 & 22 & 0.79 & 2 & 0.07 & - & - \\
\hline
\end{tabular}

\section{IV. SUMMARY OF FINDINGS, CONCLUSION AND RECOMMENDATIONS}

\section{A. Findings}

Rooted in the answers of the children, it was found that there were more girls than boys on the streets of Ozamiz. This study ascertained that not only one but three of the push factors strongly contributed to the existence of the children on the street of the city. Most of the respondents identified them as movant that make them stay on the streets at all times. These are: 1) being an orphan; 2) war (which refers to political and social unrest); and 3) natural disasters. The results do not exclude poverty. The pull factors were rated by the respondents with never. It can be gleaned also from the results of the study that verbal abuse from the public and child born on the street are the most common effects observed by the respondents; however they have rated them with sometimes.

\section{B. Conclusion}

In the light of the findings of the study it can be concluded that both push and pull factors moved the children to stay on the streets of Ozamiz City; however, push factors strongly contributed to their street existence. Meanwhile, the result for the pull factors suggested that this contributes to children's 
existence in few times. Only very few of the respondents believed that the effects mentioned in this study were commonly observed by them.

\section{Recommendations}

In the context of the findings of the study, the actions that must be done to help the children on the street do not depend solely to the parents of the respondents but also to the government and the environment. The researcher recommends that:

First, parents have to expand the love and care they have extended to their children and must be familiar on how to avoid social unrest because when the children experience social disturbances they might give the impression that they are not important in the family;

Second, government officials improve and develop more programs for the children so that in the near future there would be no more children on the street and they must enact measures to secure the innocent people when there are fights between the local rebels and the military;

Third, community officials always include in their plans the budget concerning development programs for the children of the less privileged in their areas to promote the interests, safety, health and general welfare of the children;

Fourth, local residents in the city would try to help the children on the street through making an effort to evade verbal abuse;

Fifth, academic institutions would be more responsive and further create more community extensions to help street children.

\section{REFERENCES}

[1] Philippines to Rid Metro Manila of Street Children. (1997). [Online]. Available: http://pangaea.org/street_children/asia/metro.htm

[2] Why are there Street Children. (2000). [Online]. Available: http://www.toybox.org.uk/street-children/why-are-there-street-childre n.aspx

[3] Who are the Street Children. (2011). [Online]. Available: http://gvnet.com/street children/Philippines.htm

[4] A Study on Street Children in Zimbabwe. (n.d.). [Online]. Available: http://www.unicef.org/evaldatabase/files/ZIM_01-805.pdf

[5] Beggar, Street Children Rounded Up In Zamboanga. 2006. Zamboanga Journal, Zamboanga. [Online]. Available: zamboangajournal.wordpress.com/2006/07/09/beggar-street-childrenrounded-up-in-zamboanga/

[6] S. Cullen, "Jailed children are the victims of world poverty," Preda Foundation, 2005.

[7] "Kid's World in Zamboanga". (2006). The Poor's World. Zamboanga Journal. [Online]. Available: zamboangajournal.blogspot.com/2006/05/kids-world-in-zamboanga-p oors-world.html

[8] Rescue or ruin in Manila. (2008). The Australian National University ANU News, Autumn. [Online]. Available: news.anu.edu.au/?p=457

[9] S. Damkjaer. (2008). Stairway away from Hell. ScandAsia - Denmark News. [Online]. Available: www.scandasia.com/viewNews.php?coun_code $=$ dk\& news_id $=4009$

[10] G. W. Evans. (2004). The Environment of Childhood Poverty. American Psychologist. [Online]. 59(2), pp.77-92. Available: http://psycnet.apa.org/journals/amp/59/2/77/
[11] The State of the World's Children 2006. (2005). United Nations Children's Fund. [Online]. Available: http://www.unicef. org/sowc06/pdfs/sowc 06_fullreport.pdf

[12] S. Baldauf. (2002). Poverty forces Kabul parents to send kids to orphanages. The Christian Science Monitor. [Online]. Available: http://www.csmonitor.com/ 2002/0603/p08s01-wosc.html

[13] Children's situation in Japan. (2013). [Online]. Available: http://resourcecentre.savethechildren.se/start/countries/japan

[14] M. Abbugao. (2013). Yolanda death toll feared to hit 7,000. Agence France-Presse. [Online]. Available: http://www.gmanetwork.com/news/story/336799/news/nation/yolanda -death-toll-feared-to-hit-7-000

[15] J. Stover, L. Bollinger, N. Walker, and R. Monasch. (2007). Resource needs to support orphans and vulnerable children in sub-Saharan Africa. Health Policy Plan. [Online]. Available: http://heapol.oxfordjournals.org/content/22/1/21.full

[16] M. A. E. Koumi et al. (2012). Psychiatric Morbidity among a Sample of Orphanage Children in Cairo. International Journal of Pediatrics. [Online] pp. 7. Available: http://www.hindawi.com/journals/ijpedi/ 2012/141854/

[17] S. A. Saenger. (2000). Family Violence: A Review of the Dysfunctional Behavior Patterns. [Online]. Available: http://www.mincava.umn.edu/documents/familyviolence/familyviolen ce.html

[18] G. Schäfer. (2011). Social Policy Journal of New Zealand: Family functioning in families with alcohol and other drug addiction. [Online] issue $37 . \quad$ Available: https://www.msd.govt.nz/about-msd-and-our-work/publications-resou rces/journals-and-magazines/social-policy-journal/spj37/37-family-fu nctioning-in-families-with-alcohol-and-other-drug-addiction.html

[19] N. Dizon. (2009). "Selective vigilantism' in Davao". Philippine Daily Inquirer. Manila. globalnation. [Online]. Available: https://inquirer.net/cebudailynews/news/view/20090405-198055/\%91 Selective_vigilantism\%92_in_Davao_\%96_CHR_chief

[20] L. Talusan and C. Israel, Street Children of the Philippines, Christian Broadcasting Network CBN News, Manila, 2006.

[21] The Department of Labor's 2004 Findings on the Worst Forms of Child Labor. (2005). U.S. Dept of Labor Bureau of International Labor Affairs. [Online]. Available: www.dol.gov/ilab/media/reports/iclp/tda2004/philippines.htm

[22] Human Rights Watch Street Children. (n.d.). [Online]. Available: http://www.hrw.org/children/street.htm

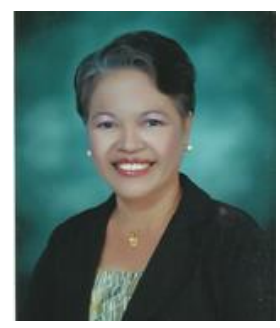

Anna C. Bocar became a committee member of international conference on management, leadership and governance - ICMLG 2013, and was born in Ozamiz City, Misamis Occidental, Mindanao, Philippines on September 17, 1961. She obtained the degree of bachelor of laws at Misamis University, 1996; and master in business administration at Immaculate Conception College-La Salle, 2000, in Ozamiz City, Philippines. She got her doctor of business administration degree at the University of San Jose Recoletos, in Cebu City, Philippines, 2006

She was the coordinator of Social Science Department, director of human resource, and currently the DBA program head and professor in the College of Business and Economics at La Salle University, Ozamiz. Her interests in research are in but not limited to social issues, information and communication technology, education, and politics.

Dr. Anna C. Bocar is also a committee member of the 2 nd international conference on management, leadership and governance - ICMLG 2014 and one of technical program committee members (TPCM) at the 4th annual international conference of political science, sociology and international relation (PSSIR). She was awarded as one of the outstanding researchers of the Philippines 2013 last November during the asian conference on multidisciplinary research in higher education (ACMRHE 2013) held in Manila, Philippines. Her papers can be accessed on the social science research network (SSRN). 